\title{
ANALISIS PENGGUNAAN MODEL AKTIVITAS RUNNING UPHILL TERHADAP PENINGKATAN GLUCOSE UPTAKE PADA MENCIT DIABETES
}

\author{
Havid Yusuf ${ }^{*}$, Rubbi Kurniawan ${ }^{2}$ \\ ${ }^{1,2}$ Pendidikan Jasmani Kesehatan dan Rekreasi, FPIEK, IKIP Budi Utomo Malang
}

"Corresponding author: havidyusuf@gmail.com

\section{A RT ICLE INFO}

Article history:

Received 08 June 16

Received in revised form 12 July 16

Accepted 23 August 16

Jenis huruf Times New Roman (8)

Keywords:

Glucose uptake, diabetes, running uphill

activities
A B S T R A C T

Diabetes is a disease in which there is an increase in blood glucose. Improvement occurs because the pancreas does not release insulin so that the glucose could not get into the muscle. Diabetes insulin receptors on muscle response to stimulation inhibits insulin, but still able to respond to stimulation of muscle contraction. Body activity in people with diabetes have an important role in controlling blood glucose levels, which is when the body activity increased glucose uptake (glucose uptake) by the muscle so that can directly cause a decrease in glucose in the bloodstream. Types of activities that can be done is a dynamic activity in the form of concentric running uphill in a move to lower glucose levels in the bloodstream. The purpose of this study to prove the use of models running uphill to the increased activity of glucose uptake in diabetic mice. This study was an experimental study with design The Randomize Post Test Only Control Group Design. Samples were divided into three groups with different test analysis results randomization delta blood glucose (DGD) showed that there are significant differences between the groups with group $\mathrm{DM}+\mathrm{DM}$ concentric $(\mathrm{p}<0.05)$ with $\mathrm{t}$ value greater than $0(\mathrm{t}>0)$. This study shows that the activity of uphill running is more effective in improving glucose uptake (glucose uptake) of the uphill running without giving activity in mice with diabetes

\section{PENDAHULUAN}

Penderita diabetes dari tahun ke tahun mengalami peningkatan. Diabetes sendiri adalah suatu penyakit dimana GLUT-4 mengalami gangguan perpindahan ke bagian membran otot akibat resistensi insulin. Resistensi insulin pada penderita diabetes menghambat respon otot terhadap rangsangan insulin dari pankreas, namun otot tetap dapat merespon rangsangan dari kontraksi (Alessio, 2006). Penderita diabetes membutuhkan bantuan selain insulin berupa aktivitas tubuh melalui rangsangan kontraksi. Rangsangan berupa kontraksi akan meningkatkan transporter glukosa yang berada pada sel otot sehingga glukosa yang ada di dalam aliran darah dapat masuk ke dalam sel otot (Esteghamati, 2008).

Aktivitas tubuh pada penderita DM memiliki peranan yang sangat penting dalam mengendalikan kadar gula dalam darah, dimana saat melakukan aktivitas tubuh terjadi peningkatan ambilan glukosa oleh otot yang aktif sehingga secara langsung dapat menyebabkan penurunan glukosa darah (Indriyani, 2007). Penurunan protein transporter glukosa ditemukan pada membran sel otot rangka penderita diabetes.GLUT-1 bertanggung jawab memfasilitasi ambilan glukosa otot. Penurunan ekspresi GLUT-1 otot diabetes menyebabkan fasilitasi ambilan glukosa terganggu, kadar glukosa darah meningkat tinggi (Ciaraldi et al., 2005).

Tujuan penelitian ini membuktikan penggunaan model aktivitas running uphill terhadap peningkatan ambilan glukosa (glucose uptake) pada hewan coba yaitu mencit diabetes. Penelitian ini dapat dijadikan sebagai alternatif aktivitas bagi penderita diabetes untuk meningkatkan ambilan glukosa dari dalam darah ke otot sehingga dapat menurunkan kadar glukosa dalam darah melalui jenis kontraksi otot.

\section{METODE}

Penelitian ini merupakan penelitian eksperimen dengan rancangan The Randomize Post Test Only Control Group Design. Sampel penelitian dibagi menjadi 3 kelompok dengan randomisasi. Kelompok 1 adalah kelompok kontrol normal tanpa induksi. Kelompok 2 dan kelompok 3 adalah sama-sama kelompok mencit dengan sampel diabetes namun dengan perlakuan berbeda. Masing-masing kelompok 9 ekor mencit. Kelompok 2 diberi perlakuan aktivitas tubuh biasa, sedangkan kelompok 3 diberi perlakuan aktivitas running uphill. Perlakuan pada setiap subjek dalam sampel pada kelompok 2 dan 3 adalah sama yaitu diinduksi streptozotocin dosis $150 \mathrm{mg} / \mathrm{kg}$ bb ip).Penelitian ini menggunakan subjek mencit sebagai model diabetes. Subjek eksperimen pada penelitian ini adalah mencit (Mus musculus) yang terdapat di kandang hewan coba Departemen Biokimia Fakultas Kedokteran Universitas Airlangga. Penelitian dilakukan di Fakultas Kedokteran Universitas Airlangga. Subjek eksperimen adalah mencit dewasa dengan jenis kelamin jantan usia 8-12 minggu, sehat dan aktif, berat badan antara 20-25 gram. Mencit diberi perlakuan dengan aktivitas running uphill menggunakan treadmill colombus dengan cara berlari dengan sudut elevasi 5 derajat dan kecepatan $21 \mathrm{~cm} /$ detik selama 12.15 detik. Mencit tanpa perlakuan diberi aktivitas fisik biasa selama 12.15 detik di dalam treadmill. Ambilan glukosa dapat dilihat dari perbandingan selisih kadar glukosa darah sebelum diberi perlakuan dan sesudah diberi perlakuan. Kadar glukosa pada mencit di dapat salah satunya melalui ekor mencit dengan cara dipotong sedikit bagian ujung ekornya. Pemeriksaan kadar glukosa melalui tetesan darah yang ditaruh stik glukosa. Stik kemudian dimasukkan ke dalam glukometer. Glukometer akan menunjukkan hasil kadar glukosa dalam darah pada hewan coba. 


\section{HASIL DAN PEMBAHASAN}

Berdasarkan hasil penelitian yang telah dilakukann, diperoleh data berat badan (BB), kadar glukosa darah puasa (GDP), kadar glukosa darah post prandial (GDPP), dan selisih glukosa darah (dGP) mencit masing-masing kelompok sebagai berikut.

Tabel 1.1 Rerata dan simpangan baku berat badan kadar glukosa darah mencit masing-masing kelompok.

\begin{tabular}{|c|c|c|c|}
\hline \multirow{3}{*}{ Behryel } & \multicolumn{3}{|c|}{ Ranth:D } \\
\hline & QD? & GDP & $(C D)$ \\
\hline & $\operatorname{lng}(0)$ & (당) & $\operatorname{lng} t)$ \\
\hline $\operatorname{Inm}\left(\mathbb{A}_{4}\right)$ & $621=211 \quad 164=3761$ & $16+14=16$ & $1+4=4$ \\
\hline $\mathrm{DM}\left(\mathrm{A}_{\mathrm{T}}\right)$ & $216=265 \quad 8012=104$ & $3+33=114,6$ & $811=164$ \\
\hline DWHAwath $(\mathbb{A})$ & $2111=316 \quad 33336=9,39$ & $2472=818$ & $-1933=481$ \\
\hline
\end{tabular}

Berdasarkan tabel 1.1 di atas didapatkan rata-rata berat badan sesudah diberikan perlakuan berupa aklimatisasi. Berat badan mencit pada kelompok normal $\left(\mathrm{K}_{0}\right)$ memiliki rata-rata $26,22( \pm 2,11)$, yaitu lebih tinggi dari pada kelompok DM $\left(\mathrm{K}_{1}\right) \quad(21,67 \pm 2,65)$ dan kelompok DM+Konsetrik $\left(\mathrm{K}_{2}\right)(22,11 \pm 3,86)$ setelah perlakuan. GDP mencit setelah induksi STZ pada $K_{1}$ dan $K_{2}$ meningkat di atas $200 \mathrm{ml} / \mathrm{dl}$ dengan rata-rata GDP $K_{1}$ sebesar 258,22 $( \pm 138,4)$ dan GDP $K_{2} 333,56(90,79)$. Rata-rata selisih glukosa darah (dGD) pada $\mathrm{K}_{1}(89,11 \pm 106,47)$ lebih tinggi dari pada $\mathrm{K}_{0}(1,44 \pm 64,2)$ dan $\mathrm{K}_{2}(-109,33 \pm 90,81)$.

Uji beda delta Glukosa Darah (dGD) digunakan untuk membuktikan apakah terdapat perbedaan yang signifikan antara kelompok kontrol diabetes dengan kelompok diabetes perlakuan terhadap peningkatan ambilan glukosa pada mencit diabetes setelah melakukan aktifitas. Terdapat perbedaan yang signifikan apabila nilai signifikansi lebih kecil dari nilai $\alpha(p<0,05)$. Berikut ini adalah hasil uji beda antar kelompok menggunakan uji t.

Tabel 1.2 Uji Beda dGD

\begin{tabular}{|lcc|}
\hline & Nilai $\boldsymbol{p}$ (sig) & Nilai t \\
\hline DM & 0,001 & 4,254 \\
\hline DM+Konsentrik & & \\
\hline & & \\
& & \\
\hline
\end{tabular}

Berdasarkan tabel 1.2 di atas diperoleh hasil bahwa terdapat perbedaan yang signifikan antara kelompok DM $\left(\mathrm{K}_{1}\right)$ dengan kelompok DM+Konsentrik $\left(\mathrm{K}_{2}\right)$ terhadap selisih glukosa darah (dGD)yang ditunjukkan dengan nilai signifikansi lebih kecil dari nilai $\alpha(p<0,05)$. Nilai t pada tabel 4.5 di atas juga menunjukkan nilai positif $(t>0)$, hal ini menunjukkan bahwa peningkatan ambilan glukosa (glucose uptake) pada mencit diabetes setelah pemberian aktivitas running uphill lebih tinggi daripada mencit diabetes tanpa pemberian aktivitas running uphill.

Berdasarkan hasil analisis di atas dapat diartikan bahwa aktivitas fisik berupa running uphill (latihan konsentrik) dapat memberikan efek penurunan glukosa darah pada mencit diabetes. Ketika terjadi kontraksi konsentrik, aktin dan myosin saling mendekat sehingga terjadi pemendekan sarkomer. Pemendekan otot saat kontraksi menghasilkan tegangan pada sarkomer yang melibatkan protein aktin dan myosin (Bubbico, 2010). Proses kontraksi konsenrtik ini menyebabkan stimulasi transporter glukosa melalui sel otot, sehingga ambilan glukosa darah dalam otot meningkat.

Kontraksi otot menyebabkan pelepasan ion $\mathrm{Ca}^{2+}$ dari retikulum sarkoplasma (Rose, 2005). Peningkatan konsentrasi $\mathrm{Ca}^{2+}$ di dalam plasma sel (sitosol) memicufosforilasi enzim CaMK II (calmodulin-dependent protein kinase II), yaitu enzim yang memiliki peran penting dalam regulasi glukosa. Enzim CaMK II melepaskan ikatan $\mathrm{Ca}^{2+}$ pada $\mathrm{CaM}$, sehingga $\mathrm{Ca}^{2+}$ menstimulasi translokasi GLUT-4 ke permukaan membran sel (Rose, 2005).

\section{SIMPULAN DAN REKOMENDASI}

Berdasarkan masalah dan hasil analisis data penelitian yang dilakukan, disimpulkan bahwa aktivitas biasa (tanpa running uphill) tidak dapat meningkatkan ambilan glukosa (glucose uptake) pada mencit diabetes. Aktivitas running uphill dapat meningkatkan ambilan glukosa (glucose uptake) pada mencit diabetes. Terdapat perbedaan yang signifikan dGD antara aktifitas biasa dengan aktivitas running uphill, yang dimana aktivitas running uphill lebih efektif dalam meningkatkan ambilan glukosa dari pada aktivitas biasa.

Peneliti masih menggunakan mencit sebagai sampel perlakuan untuk penelitian ini. Diharapkan penelitian selanjutnya bisa menggunakan sampel manusia agar hasil penelitian bisa lebih maksimal

\section{REFERENCES}

Alessio, H.M. and Hagerman, A.E. 2006. Oxidative Stress, Exercise and Aging. Imperial College Press: London.

Bubbico, A. and Kravitz, L. 2010. "Eccentric Exercise: A Comprehensive Review of a Distinctive Training Method". IDEA Fitness Journal. Vol. 7 No. 9 , pp. 50-59.

Ciaraldi, T.P.,Mudaliar, S., Barzin, A., Macievic, J.A., Edelman S.V., Park K.S. and Henry, R.R. 2005. "Skeletal Muscle GLUT-1 Transporter Proteine Expression \& Basal Leg Glucose Uptake are Reduced in Type 2 Diabetes". Journal of Clinical Endocrinology and Metabolism. Vol. 90, pp. 352-358.

Esteghamati, A., Hassabi, M., Halabchi, F., Bagheri, M. 2008."Exercise Prescription in Patients with Diabetes Type 2".Iranian Journal of Diabetes and Lipid Disorders. Vol. 8, pp. 1-15.

Indriyani, P., Supriyatno, H., Santoso, A. 2007. "Pengaruh Latihan Fisik SenamAerobik Terhadap Penurunan Kadar Gula Darah pada Penderita DM Tipe 2 di Wilayah Puskesmas Bukateja Purbalingga”. Media Ners . (Diaksespada tanggal 23 Oktober 2012).

Rose, A.J. and Richter, E.A. 2005. "Skeletal Muscle Glukosa Uptake During Exercise: How is it Regulated?". Physiology. Vol. 20, pp. 260-270. 